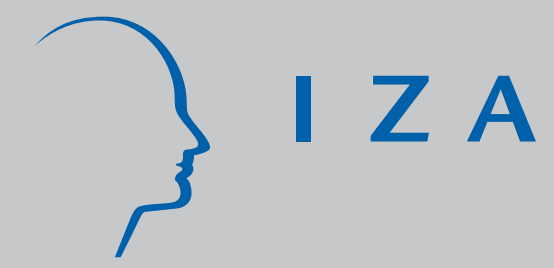

IZA DP No. 221

Wages as Risk Compensation in Germany

Christian Grund

December 2000 


\title{
Wages as Risk Compensation in Germany
}

\author{
Christian Grund \\ University of Bonn and IZA, Bonn \\ Discussion Paper No. 221 \\ December 2000 \\ IZA \\ P.O. Box 7240 \\ D-53072 Bonn \\ Germany \\ Tel.: +49-228-3894-0 \\ Fax: +49-228-3894-210 \\ Email: iza@iza.org
}

This Discussion Paper is issued within the framework of IZA's research area The Future of Work. Any opinions expressed here are those of the author(s) and not those of the institute. Research disseminated by IZA may include views on policy, but the institute itself takes no institutional policy positions.

The Institute for the Study of Labor (IZA) in Bonn is a local and virtual international research center and a place of communication between science, politics and business. IZA is an independent, nonprofit limited liability company (Gesellschaft mit beschränkter Haftung) supported by the Deutsche Post AG. The center is associated with the University of Bonn and offers a stimulating research environment through its research networks, research support, and visitors and doctoral programs. IZA engages in (i) original and internationally competitive research in all fields of labor economics, (ii) development of policy concepts, and (iii) dissemination of research results and concepts to the interested public. The current research program deals with (1) mobility and flexibility of labor markets, (2) internationalization of labor markets and European integration, (3) the welfare state and labor markets, (4) labor markets in transition, (5) the future of work, (6) project evaluation and (7) general labor economics.

IZA Discussion Papers often represent preliminary work and are circulated to encourage discussion. Citation of such a paper should account for its provisional character. 
IZA Discussion Paper No. 221

December 2000

\section{ABSTRACT \\ Wages as Risk Compensation in Germany*}

The theory of compensating wage differentials is generally accepted. Still, there has been no strong or even contrary evidence for compensating wage differentials in Germany so far. Estimating wage regressions with data of the German Socio-Economic Panel (GSOEP) within individually perceived hazards of work accidents as a risk variable, evidence for compensating wage differentials in Germany is found even though other effects may partly weaken the existing wage premiums due to risks at work.

JEL Classification: J28, J31

Keywords: Compensating wage differentials, wage regressions, work accidents

Christian Grund

University of Bonn

Betriebswirtschaftliche Abteilung II

Lehrstuhl für Personal- und Organisationsökonomie

Adenauerallee 24-42

D-53113 Bonn

Germany

Tel.: +49 $22873-9213$

Fax: +49 228 73-9210

E-mail: christian.grund@uni-bonn.de

* I am grateful for helpful comments from Knut Gerlach, Matthias Kräkel and Andrea E. Smolka. 


\section{Introduction}

Imagine that you have just received a degree from a college of engineering and you can choose between two interesting job offers as a result of your job search. The offers are comparable as to all essential characteristics, e.g. promotion prospects, location of plants, working hours, and especially the wages. The only difference between the two job offers is that there are irritations of noise and an increased risk of work accidents in firm A while not in firm B. Which job do you choose?- The job in firm B, of course! The only thing firm A could do, is to compensate you for worse working conditions by paying an extra bonus.

This is the idea of the theory of compensating wage differentials, which forms part of most personnel and labor economics textbooks by now (e.g. see FRANZ 1996: 328-329, BORJAS 1996: 188-219, EHRENBERG/SMITH 1997: 247-285, LAZEAR 1998: 377-407). The seminal idea bases on ADAm SMITH's theory of net advantages (see Smith 1976). Already in 1776 he assumed that people with worse working conditions get higher wages within a labor market equilibrium.

This theory is generally accepted. There exist several studies that confirm compensating wage differentials for dangerous work in the USA. ${ }^{1}$ Two papers analyze possible compensating wage differentials in Germany (see LORENZ/WAGNER 1988, BELLMANN 1994). Surprisingly, LORENZ and WAGNER cannot find any evidence for risk compensations and BELLMANN only observes these premiums for increased probabilities of fatal but not of nonfatal accidents.

The results of this paper will show that compensating wage differentials for dangerous work do exist in Germany as well, even though other effects, such as a sorting mechanism of employees, may weaken the risk compensation. A short summary of the empirical results of

\footnotetext{
${ }^{1}$ See VisCuSi (1993) for a summary of these studies and Dorman/HAGSTROM (1998) for a critical view.
} 
the German and the U.S. studies is given in Section 2. In Section 3 compensating wage differentials are analyzed on the basis of wage regressions using perceived individual hazards of work accidents as a risk variable according to the data of the Socio-Economic Panel (GSOEP). The paper closes with a discussion of the results.

\section{Empirical results of earlier studies}

Several studies identify the relevance of compensating wage differentials for dangerous work in the U.S. labor market. VISCUSI (1993) gives a summary of these studies. Most approaches use industry wide averages of fatal and non-fatal work accidents as risk variables and find compensating wage differentials for both categories. VISCUSI (1993: 1928) mentions that „the main deficiency of industry-based data is that they pertain to industry-wide averages and do not distinguish among the different jobs within that industry". That is why the results could rather be interpreted as industry wage premiums than risk premiums (see DORMAN/HAGSTROM 1998: 117). Following this assumption Dorman/HaGSTROM (1998) in a recent study include industry-level variables (e.g. value added per worker and union density) and find reduced evidence for compensating wage differentials in the U.S.

Only two empirical papers deal explicitly with compensating wage differentials in Germany so far. ${ }^{2}$ LORENZ and WAGNER analyze the effects of fatal as well as non-fatal accidents at work and occupational illnesses on monthly net wages in the early 1980 s within five German samples. Their risk variables are based not on industry but occupational averages. They could not observe individual risks due to lack of data. LORENZ and WAGNER estimate wage

\footnotetext{
${ }^{2}$ Additionally SCHMIDT and ZIMMERMANN (1991) use a dummy for hazardous work as a control variable in their wage regression on the basis of data from 1978 of the Zentralarchiv für Empirische Sozialforschung zu Köln. They find weak evidence for risk premiums due to hazardous work.
} 
regressions for male full-time employees using schooling, experience (and its square), tenure, firm size as well as dummies for overhours, university degree and executive position as control variables. If compensating wage differentials could be discerned, the coefficients of the risk variables should be significantly positive. But none of the 20 coefficients fulfills this requirement. In contrast, their results even show significantly negative coefficients for nonfatal accidents at work.

BELLMANN (1994) uses the same average occupational risk variables and additionally observes their effects on the loss of life expectancy. He bases his study on the employment sample of the German Institute of Employment Research (IAB) of 1979. He restricted his approach to blue collar workers and finds significant positive effects of fatal accidents at work and non-fatal occupational illnesses of male employees, controlling schooling, experience (and its square) and change of industry. Still, in accordance with LORENZ and WAGNER, the coefficients for non-fatal accidents of work are significantly negative. Hence, there is no explicit evidence for the existence of compensating wage differentials, especially for non-fatal risks, in Germany so far.

The authors partly explain their results with their unprecise risk variables. The use of average occupational risks might be too rough an estimate for personal risks of work accidents. Strictly speaking, LORENZ/WAGNER and BELLMANN measure - due to restrictions of their data sets - inter-occupational wage differentials, which cannot be equated with compensating wage differentials for hazardous work necessarily. Some occupations are more likely to occur in huge firms and in industries with above average wages, for example. ${ }^{3}$ LORENZ/W AGNER (1988: 379) bear hope for further empirical work with better data.

\footnotetext{
${ }^{3}$ See GERLACH/HÜBLER (1998) for evidence and explanations of firm size wage differentials and HAISKENDENEW/SCHMIDT (1994) for inter-industry wage differentials in Germany.
} 
This problem is approached in the following empirical study, where for the first time personal assessments of work accidents are included in wage regressions and are controlled by several independent variables.

\section{Data and methodology}

The following study bases on data from the German Socio-Economic Panel (GSOEP), a yearly sample survey of persons living in Germany. ${ }^{4}$ Some limitations are made for the sample of this study. Only male full-time employees of 1995 are observed. The observation period is restricted to 1995 because the risk variable is sampled only in this year. A sample size of 2460 employees arises due to this limitations.

The persons have to respond to the question whether they ,,are exposed to an increased risk of work related accidents“. 5 Three categories of answers are allowed: ,applies fully“, „applies partly“ and „does not apply“. Hence, in contrast to prior studies, we have a variable for individual risks and not only industry or occupational averages of risks. Though this variable is based on a subjective perception, its meaningfulness is considerable. It can be argued that in reality employers recompense only perceived increased risks. ${ }^{6}$ A certain disadvantage of this risk variable consists in the fact that it is only an ordinal variable. Hence, it is not possible, as in other studies, to make quantitative statements with regard to returns to a percentage increase of the probability of work accidents.

Several other independent variables are included in the regression in order to take into account further wage determinants. The age and its square, tenure, working hours and

\footnotetext{
${ }^{4}$ The data is available at the German Institute for Economic Research (DIW), Berlin.

${ }^{5}$ See the questionnaire of the GSOEP at http://www.diw.de/soep/soepinfo.

${ }^{6}$ See KUNREUTHER et al. (1978) for empirically observed barriers of perception in decision making.
} 
dummy variables for marital status, schooling degrees, vocational degrees, firm sizes, occupational status and industries form part of these variables. ${ }^{7}$ This is another difference to the quoted prior German studies, which control only for a few independent variables. It should be kept in mind that inter-industry wage differentials are separated from compensating wage differentials due to this approach in contrast to many other studies.

Simple OLS wage regressions are estimated with the log of gross monthly wages as the dependent variable (LNWAGE). Except for a general computation of the whole sample, further regressions of sub-groups (blue-collars, white-collars, West-Germany, East-Germany) are estimated in order to find out possible differences between these groups. ${ }^{8}$ Compensating wage differentials will be found, if the coefficients of the dummies of partly increased risk of work accidents (PARTRISK), and especially fully increased risk of work accidents (FULLRISK), are significantly positive.

\section{Empirical results}

The perceived risks of accidents at work are remarkable. A partly increased risk of work accidents is indicated by $38 \%$ of the employees and $17 \%$ are even affected by a fully increased risk of work accidents. The descriptive statistics of these and the other variables can be found in table 1.

\footnotetext{
${ }^{7}$ See table 1 for a complete list of the descriptions and names of these variables.

${ }^{8}$ These distinctions are made, because blue-collar workers are much more affected by work accidents than white-collars and the East-German labor market differs remarkably from the West-German one, e.g. with regard to the rate of unemployment.
} 
Table 1: Descriptive statistics of variables

\begin{tabular}{|c|c|c|c|}
\hline Variable & Name & Average & $\begin{array}{l}\text { Standard } \\
\text { Deviation }\end{array}$ \\
\hline $\ln$ (gross monthly wage) (in DM) & LNWAGE & 8.321 & 0.358 \\
\hline Age (in years) & AGE & 40.13 & 10.76 \\
\hline Age * Age & SQAGE & 1726.3 & 895.8 \\
\hline Tenure (in years) & TENURE & 11.10 & 9.798 \\
\hline Marital status (dummy for married) & MARRIED & 0.742 & 0.438 \\
\hline Dummy for East-Germany & EAST & 0.310 & 0.463 \\
\hline Working hours (per week) & HOURS & 43.80 & 7.280 \\
\hline $\begin{array}{l}\text { Schooling dummies: } \\
\text { No school degree }\end{array}$ & NOSCHOOL & 0.057 & 0.233 \\
\hline „Hauptschule“ degree (9 years) & HAUPT (base) & 0.385 & 0.487 \\
\hline „Realschule“ degree (10 years) & SECONDARY & 0.292 & 0.455 \\
\hline „Fachabitur“ (12 years) & SPEC-A-LEVEL & 0.038 & 0.191 \\
\hline „Abitur“ (13 years) & GEN-A-LEVEL & 0.127 & 0.333 \\
\hline Other school degree & OTHER & 0.101 & 0.301 \\
\hline $\begin{array}{l}\text { Vocational dummies: } \\
\text { No education }\end{array}$ & NOEDUC & 0.158 & 0.365 \\
\hline Vocational training & VOCATION (base) & 0.724 & 0.447 \\
\hline University degree & UNIVERSITY & 0.118 & 0.323 \\
\hline Less than 5 employees & SIZE1 & 0.046 & 0.209 \\
\hline - 5 to 19 employees & SIZE2 & 0.157 & 0.363 \\
\hline - 20 to 199 employees & SIZE3 (base) & 0.300 & 0.458 \\
\hline - 200 to 1999 employees & SIZE4 & 0.252 & 0.434 \\
\hline - 2000 and more employees & SIZE5 & 0.246 & 0.431 \\
\hline$\frac{\text { Risk dummies: }}{\text { No increased risk of work accident }}$ & NORISK (base) & 0.453 & 0.498 \\
\hline Partly increased risk of work accident & PARTRISK & 0.383 & 0.486 \\
\hline Fully increased risk of work accident & FULLRISK & 0.165 & 0.371 \\
\hline
\end{tabular}

Source: GSOEP 1995, own calculations.

Table 2 shows the results of the wage regressions. Before this study focuses on the risk variable it should be mentioned that in accordance with the theory of human capital positive returns to age (as a proxy for experience), tenure, schooling and education can be observed. Furthermore, higher wages for West-German employees, for longer working hours, and for people working in huge firms are no surprising results either. 
Table 2: Wage regressions of male full-time employees (absolute T-values in parentheses)

\begin{tabular}{|c|c|c|c|c|c|}
\hline \multirow[b]{2}{*}{$\begin{array}{l}\text { Independent } \\
\text { Variable }\end{array}$} & \multicolumn{5}{|c|}{ Dependent variable: log of gross monthly wages } \\
\hline & $\begin{array}{l}\text { Whole } \\
\text { Sample }\end{array}$ & $\begin{array}{c}\text { Blue } \\
\text { Collars }\end{array}$ & $\begin{array}{l}\text { White } \\
\text { Collars }\end{array}$ & $\begin{array}{c}\text { West- } \\
\text { Germany }\end{array}$ & $\begin{array}{c}\text { East- } \\
\text { Germany }\end{array}$ \\
\hline CONST. & $\begin{array}{l}+7.363 * * * \\
(92.19)\end{array}$ & $\begin{array}{l}+7.488^{* * * *} \\
(79.46)\end{array}$ & $\begin{array}{l}+6.982 * * * * \\
(46.63)\end{array}$ & $\begin{array}{l}+7.053^{* * *} \\
(77.38)\end{array}$ & $\begin{array}{l}+7.677^{* * * *} \\
(46.20)\end{array}$ \\
\hline AGE & $\begin{array}{l}+0.0242 * * * \\
(6.538)\end{array}$ & $\begin{array}{l}+0.0226 * * * \\
(5.195)\end{array}$ & $\begin{array}{l}+0.0427 * * * \\
(6.166)\end{array}$ & $\begin{array}{l}+0.0323 * * * \\
(7.812)\end{array}$ & $\begin{array}{l}+0.0031 \\
(0.390)\end{array}$ \\
\hline SQAGE & $\begin{array}{l}-0.00027 * * * \\
(6.130)\end{array}$ & \begin{tabular}{|l}
$-0.00027 * * * *$ \\
$(5.155)$
\end{tabular} & $\begin{array}{l}-0.00045^{* * * *} \\
(5.667)\end{array}$ & \begin{tabular}{|l}
$-0.00035^{* * * *}$ \\
$(7.230)$
\end{tabular} & $\begin{array}{l}-0.00004 \\
(0.469)\end{array}$ \\
\hline TENURE & $\begin{array}{l}+0.0020 * * * \\
(3.220)\end{array}$ & $\begin{array}{l}+0.0011 \\
(1.414)\end{array}$ & $\begin{array}{l}+0.0031 \text { *** } \\
(2.946)\end{array}$ & $\begin{array}{l}+0.0018 * * \\
(2.384)\end{array}$ & $\begin{array}{l}+0.0009 \\
(0.814)\end{array}$ \\
\hline MARRIED & $\begin{array}{l}+0.0522 * * * \\
(4.459)\end{array}$ & $\begin{array}{l}+0.0242 * \\
(1.724)\end{array}$ & $\begin{array}{l}+0.0768 * * * \\
(3.697)\end{array}$ & $\begin{array}{l}+0.0787 * * * \\
(5.986)\end{array}$ & $\begin{array}{l}+0.0032 \\
(0.133)\end{array}$ \\
\hline EAST & $\begin{array}{l}-0.363^{* * * *} \\
(27.89) \\
\end{array}$ & \begin{tabular}{|l}
$-0.330 * * *$ \\
$(19.42)$ \\
\end{tabular} & $\begin{array}{l}-0.401 * * * \\
(19.13) \\
\end{array}$ & & \\
\hline HOURS & $\begin{array}{l}+0.0072 * * * \\
(10.04)\end{array}$ & $\begin{array}{l}+0.0066 * * * \\
(7.363)\end{array}$ & $\begin{array}{l}+0.0080 * * * \\
(6.606)\end{array}$ & $\begin{array}{l}+0.0100 * * * \\
(10.92)\end{array}$ & $\begin{array}{l}+0.0036^{* * *} \\
(3.109)\end{array}$ \\
\hline NOSCHOOL & $\begin{array}{l}-0.0634 * * * \\
(2.873)\end{array}$ & $\begin{array}{l}-0.0519 * * \\
(2.271)\end{array}$ & $\begin{array}{l}+0.0138 \\
(0.240)\end{array}$ & $\begin{array}{l}-0.0691 * * * \\
(3.226)\end{array}$ & $\begin{array}{l}+0.0967 \\
(0.568)\end{array}$ \\
\hline SECONDARY & $\begin{array}{l}+0.0649 * * * \\
(4.849)\end{array}$ & $\begin{array}{l}+0.0397 * * \\
(2.351)\end{array}$ & $\begin{array}{l}+0.0872 * * * \\
(3.789)\end{array}$ & $\begin{array}{l}+0.0503 * * * \\
(3.006)\end{array}$ & $\begin{array}{l}+0.0517 * * \\
(2.047)\end{array}$ \\
\hline SPEC-A-LEVEL & $\begin{array}{l}+0.0323 \\
(1.222) \\
\end{array}$ & $\begin{array}{l}+0.0467 \\
(0.864)\end{array}$ & \begin{tabular}{|l|}
+0.0508 \\
$(1.462)$
\end{tabular} & $\begin{array}{l}+0.0179 \\
(0.679)\end{array}$ & $\begin{array}{l}+0.590 * * \\
(2.291)\end{array}$ \\
\hline GEN-A-LEVEL & $\begin{array}{l}+0.0531 * * \\
(2.484)\end{array}$ & $\begin{array}{l}+0.0070 \\
(0.170)\end{array}$ & $\begin{array}{l}+0.0971 * * * \\
(3.247)\end{array}$ & $\begin{array}{l}+0.0768 * * * \\
(3.024)\end{array}$ & $\begin{array}{l}+0.0323 \\
(0.807)\end{array}$ \\
\hline OTHER & $\begin{array}{l}-0.0748 * * * \\
(4.258)\end{array}$ & $\begin{array}{l}-0.0552 * * * \\
(3.097)\end{array}$ & $\begin{array}{l}-0.0481 \\
(0.857)\end{array}$ & $\begin{array}{l}-0.0775^{* * *} \\
(4.480)\end{array}$ & $\begin{array}{l}+0.0194 \\
(0.073)\end{array}$ \\
\hline NOEDUC & $\begin{array}{l}-0.0227 \\
(1.489)\end{array}$ & \begin{tabular}{|l|}
-0.0043 \\
$(0.274)$
\end{tabular} & $\begin{array}{l}-0.108 * * \\
(2.514)\end{array}$ & \begin{tabular}{|l|}
-0.0101 \\
$(0.668)$
\end{tabular} & $\begin{array}{l}-0.0887 \\
(1.356)\end{array}$ \\
\hline UNIVERSITY & $\begin{array}{l}+0.121 \text { *** } \\
(5.688)\end{array}$ & \begin{tabular}{|l}
+0.0665 \\
$(1.022)$
\end{tabular} & $\begin{array}{l}+0.113 * * * \\
(4.378)\end{array}$ & $\begin{array}{l}+0.130 * * * \\
(5.328)\end{array}$ & $\begin{array}{l}+0.102 * * \\
(2.420)\end{array}$ \\
\hline SIZE1 & $\begin{array}{l}-0.134 * * * \\
(5.828)\end{array}$ & $\begin{array}{l}-0.142 * * * \\
(5.625)\end{array}$ & $\begin{array}{l}-0.104 * * \\
(2.257)\end{array}$ & $\begin{array}{l}-0.121 * * * \\
(4.205)\end{array}$ & $\begin{array}{l}-0.168 * * * \\
(4.423)\end{array}$ \\
\hline SIZE2 & $\begin{array}{l}-0.0761 * * * \\
(5.267)\end{array}$ & $\begin{array}{l}-0.0872 \text { *** } \\
(5.391)\end{array}$ & $\begin{array}{l}-0.0571^{* * *} \\
(2.011)\end{array}$ & $\begin{array}{l}-0.0514 * * * \\
(2.853)\end{array}$ & $\begin{array}{l}-0.122 * * * \\
(5.040)\end{array}$ \\
\hline SIZE4 & $\begin{array}{l}+0.0585 * * * \\
(4.591)\end{array}$ & $\begin{array}{l}+0.0559 * * * \\
(3.617)\end{array}$ & $\begin{array}{l}+0.0593 * * * \\
(2.727)\end{array}$ & $\begin{array}{l}+0.0638 * * * \\
(4.413)\end{array}$ & $\begin{array}{l}+0.0578 * * \\
(2.276)\end{array}$ \\
\hline SIZE5 & $\begin{array}{l}+0.113 \text { **** } \\
(8.291)\end{array}$ & $\begin{array}{l}+0.108 * * * \\
(6.286)\end{array}$ & $\begin{array}{l}+0.112 * * * \\
(5.028)\end{array}$ & $\begin{array}{l}+0.118 * * * \\
(7.833)\end{array}$ & $\begin{array}{l}+0.0961 * * * \\
(3.160)\end{array}$ \\
\hline OCCSTATUS & yes (11) & yes (5) & yes (6) & yes (11) & yes (11) \\
\hline INDUSTRIES & yes (32) & yes (31) & yes $(31)$ & yes (32) & yes (32) \\
\hline RISKPART & $\begin{array}{l}+0.00069 \\
(0.061)\end{array}$ & $\begin{array}{l}+0.0167 \\
(1.259)\end{array}$ & \begin{tabular}{|l|}
-0.0228 \\
$(1.097)$ \\
\end{tabular} & $\begin{array}{l}+0.0016 \\
(0.124)\end{array}$ & $\begin{array}{l}-0.0138 \\
(0.637)\end{array}$ \\
\hline RISKFULL & $\begin{array}{l}+0.0299 * * \\
(1.992)\end{array}$ & $\begin{array}{l}+0.0451 \text { *** } \\
(2.790)\end{array}$ & \begin{tabular}{|l|}
-0.0416 \\
$(1.111)$ \\
\end{tabular} & $\begin{array}{l}+0.0323^{*} \\
(1.836)\end{array}$ & $\begin{array}{l}+0.0100 \\
(0.361)\end{array}$ \\
\hline$\overline{R_{\text {adj. }}^{2}}$ & 0.618 & 0.413 & 0.616 & 0.608 & 0.440 \\
\hline $\mathrm{n}$ & 2460 & 1476 & 984 & 1697 & 763 \\
\hline
\end{tabular}

Note: *, ** and ***: coefficient is significant at the $10 \%$-, $5 \%$ - and $1 \%$-level.

Source: GSOEP 1995, own calculations. 
Much more attention should be paid to the risk variables. The coefficients of both risk variables (PARTRISK and FULLRISK) are positive within the regression of the whole sample. Additionally, the result for FULLRISK is significant at the 95\%-level. Employees with fully increased risks of accident at work get an average wage premium in the amount of $3 \%$ as compared to people without increased dangers of work accidents. ${ }^{9}$ The regressions of the separate groups show that this result does not hold for all subgroups. Significant compensating wage differentials due to the risk of work accidents can only be observed for blue-collar employees and in West-Germany, but not for white-collars and East-German employees. The returns due to FULLRISK are $4.6 \%$ for blue-collars and $3.3 \%$ in WestGermany, respectively. In contrast, there are even (insignificantly) negative returns to risks for white-collars. The following section discusses these results and gives an explanation.

\section{Discussion}

In contrast to the prior German studies, compensating wage differentials for increased risks of work accidents can be observed particularly for blue-collar workers and in West-Germany. The main innovation of this approach lies in the fact that for the first time an individual risk variable has been included. Therefore, compensating wage differentials can be discerned in a better way, whereas prior studies measure inter-industry or occupational wage premiums rather than strictly compensating wage differentials due to restrictions of their data sets.

Several explanations of the results can be given. First of all, a measurement error is possible. HAMERMESH (1978) hypothesizes (and ELLIOTT/SANDY (1998) find evidence) that workers

\footnotetext{
${ }^{9}$ In contrast to metric variables the coefficient of dummy variables must not be directly interpreted as wage returns. These coefficients (c) have to be transformed with $g=\exp (\mathrm{c})-1$ to get the exact wage premium of the dummy relative to the base group (see HALVORSEN/PALMQUIST 1980). Still, the differences with regard to the results of this study are very small.
} 
with relative low wages, and who are thus dissatisfied with their pay, will overstate the magnitude of their risks of work accidents. Hence, the premium due to risk of work accidents could be biased downwards. Further on, a basic difference between German and U.S. labor market institutions has to be mentioned. In contrast to the U.S., an insurance against work accidents is part of the German social security system. ${ }^{10}$ People are compensated ex post at least for non-fatal risks of work accidents. Hence, risky work has only partly to be compensated ex ante through higher wages by the employer and so compensating wage differentials are more likely to be observed in the U.S. labor market.

Some further explanations can be given as to the question why there is no evidence for compensating wage differentials for white-collar workers and in East-Germany. An essential assumption within the theory of compensating wage differentials is the existence of an competitive labor market. This assumption has to be regarded critically especially with respect to the East-German labor market. During the first years after the German unification many employees lost their jobs. The regional rate of unemployment was $14.9 \%$ in 1995 with an increasing tendency, as opposed to only $9.3 \%$ in West-Germany. The lack of a competitive labor market accounts for the non-existence of compensating wage differentials in East-Germany. People are content to have a job and know that there is hardly a chance to get another, possibly less risky one. Hence, it is not very surprising that compensating wage differentials cannot be found in East-Germany. Additionally, people in general and particularly in East-Germany are not perfectly mobile, whereby this effect is strengthened. ${ }^{11}$

\footnotetext{
${ }^{10}$ See SCHAUENBERG (1999) for the German system of occupational cooperatives as insurers against work accidents and a comparison of the German and the U.S. system.

${ }^{11}$ More than $50 \%$ of the East-German of this sample could not imagine to change their current city of residence due to job related reasons.
} 
Table 3: Distribution of risk of work accidents within blue-collars and white-collars

\begin{tabular}{|l|c|c|}
\hline \multicolumn{1}{|c|}{ Risk variable } & $\begin{array}{c}\text { Blue } \\
\text { collars }\end{array}$ & $\begin{array}{c}\text { White } \\
\text { collars }\end{array}$ \\
\hline NORISK & 0.26 & 0.74 \\
\hline PARTRISK & 0.50 & 0.21 \\
\hline FULLRISK & 0.24 & 0.05 \\
\hline
\end{tabular}

Source: GSOEP 1995, own calculations.

Another aspect might be able to explain the differences between blue-collar and white-collar workers. Blue-collar workers are much more affected by increased risks of work accidents than white-collars (see table 3). Three quarters of white-collar employees do not perceive increased risks, whereas this holds only for one quarter of the blue-collars. This aspect alone does not yet account for the fact that compensating wage differentials can be measured for blue-collar workers only. In order to explain the phenomenon it has to be kept in mind that there will always be unobserved heterogeneity with respect to the workers' ability (see HWANG et al. 1990). ${ }^{12}$ This heterogeneity cannot be measured with this data, fact why an underlying sorting mechanism cannot be controlled for either. Only few jobs of white-collar workers bear an increased risk. Hence, high ability white-collars should have no problems in finding a job without increased risks. On the other hand, low ability white-collars partly have to be content with risky jobs. This leads to the assumption that compensating wage differentials cannot be observed because of the countervailing sorting effect in the staffing of the jobs with increased risks of work accidents.

This mechanism will not hold for blue-collars, because most jobs bear a certain risk and even high ability blue-collar employees have to accept increasing risks of work accidents. That is

\footnotetext{
12 There will be unobserved heterogeneity with respect to the workers' risk aversion as well. Very risk averse employees will choose jobs or occupations with less dangers of work accidents. This is another argument for relative small risk premiums due to work accidents in general. There would be bigger risk premiums if the employees would be allocated to jobs by chance.
} 
why a sorting mechanism is of less importance for blue-collars and compensating wage differentials can be found for blue-collars rather than white-collar workers.

Unfortunately, the risk variable is included only in the 1995 data of the GSOEP and not in that of further years, so that it is not possible to estimate panel regressions. In spite of these restrictions evidence for compensating wage differentials in Germany is found in contrast to prior German studies. 


\section{References}

Bellmann, Lutz (1994): Entlohnung als Risikokompensation. Mitteilungen aus der Arbeitsmarkt- und Berufsforschung 4 (1994), 351-358.

Borjas, George J. (1996): Labor Economics. New York et al. (1996).

Dorman, Peter; Paul Hagstrom (1998): Wage Compensation for Dangerous Work Revisited. Industrial and Labor Relations Review 52 (1998), 116-135.

Ehrenberg, Ronald G.; Robert S. Smith (1996): Modern Labor Economics. 6th ed., Reading et al. (1996).

Elliott, Robert F.; Robert Sandy (1998): Adam Smith May Have Been Right After All: A New Approach to the Analysis of Compensating Differentials. Economics Letters 59 (1998), 127-131.

Franz, Wolfgang (1996): Arbeitsökonomik. 3rd ed., Berlin et al. (1996).

Gerlach, Knut; Olaf Hübler (1998): Firm Size and Wages in Germany - Trends and Impacts of Mobility. Empirica 25 (1998), 245-261.

Haisken-De New, John P.; Christoph M. Schmidt (1994): The Industrial Structure of German Earnings 1980-1990. Allgemeines Statistisches Archiv 78 (1994), 141-159.

Halvorsen, Robert; Raymond Palmquist (1980): The Interpretation of Dummy Variables in Semilogarithmic Equations. American Economic Review 70 (1980), 474-475.

Hamermesh, Daniel S. (1978): Economic Aspects of Job Satisfaction. In: Ashenfelter, O.; W. Oates (Eds.): Essays in Labor Market Analysis. New York et al. (1978), 53-72.

Hwang, Hae S.; W. Robert Reed; Carlton Hubbard (1990): Compensating Wage Differentials and Unobserved Productivity. Journal of Political Economy 100 (1990), 835-858.

Kunreuther, H. et al. (1978): Disaster Insurance Protection. Public Policy Lessons. New York (1978).

Lazear, Edward (1998): Personnel Economics for Managers. New York et al. (1998).

Lorenz, Wilhelm; Joachim Wagner (1988): Gibt es kompensierende Lohndifferentiale. Zeitschrift für Wirtschafts- und Sozialwissenschaften 108 (1988), 371-381.

Schauenberg, Bernd (1999): Risiko und Risikoregulierung von Beschäftigungsverhältnissen. In: Wagner, G. R. (Ed.): Unternehmensführung, Ethik und Umwelt - Hartmut Kreikebaum zum 65. Geburtstag. Wiesbaden (1999), 424-453.

Schmidt, Christoph M.; Klaus F. Zimmermann (1991): Work Characteristics, Firm Size and Wages. The Review of Economics and Statistics 73 (1991), 705-710.

Smith, Adam (1976): An Inquiry into the Nature and Causes of the Wealth of Nations. Oxford (1976).

Viscusi, W. Kip (1993): The Value of Risks to Life and Health. Journal of Economic Literature 31 (1993), 1912-1946. 


\section{IZA Discussion Papers}

No Author(s)

B. R. Chiswick

132

D. N. F. Bell

R. A. Hart

O. Hübler

W. Schwerdt

134 A. D. Kugler

G. Saint-Paul

135 A. Barrett

P. J. O'Connell

136 M. Bräuninger

M. Pannenberg

J.-St. Pischke

138 J. Zweimüller

R. Winter-Ebmer

R. A. Hart

Y. Ma

140

141 R. Hujer

M. Wellner

142 J. J. Dolado

F. Felgueroso

J. F. Jimeno

143 P. J. Luke

M. E. Schaffer

144 G. Saint-Paul

145 M.-S. Yun

146 T. K. Bauer

J. P. Haisken-DeNew
Titel

Area

Date

Are Immigrants Favorably Self-Selected? An 1

$3 / 00$

Economic Analysis

Hours and Wages in the Depression: British 7 Engineering, 1926-1938

Paid and Unpaid Overtime Working in Germany and 1 the UK

Hiring and Firing Costs, Adverse Selection and 3

$3 / 00$

Long-term Unemployment

Is There a Wage Premium for Returning Irish 1

$3 / 00$

Migrants?

Unemployment and Productivity Growth: An

$3 / 00$

Empirical Analysis within the Augmented Solow

Model

Continuous Training in Germany

$3 / 00$

Firm-specific Training: Consequences for Job

$3 / 00$

Mobility

Wages, Hours and Human Capital over the

$3 / 00$

Life Cycle

Education and Earnings Growth: Evidence from $11 \quad 2 / 5$

$4 / 00$

European Countries

The Effects of Public Sector Sponsored Training on Individual Employment Performance in East

6

$4 / 00$

Germany

Explaining Youth Labor Market Problems in Spain: 3

$4 / 00$ Crowding-Out, Institutions, or Technology Shifts?

Wage Determination in Russia: An Econometric 4

$4 / 00$ Investigation

Flexibility vs. Rigidity: Does Spain have the worst of 1 both Worlds?

$4 / 00$

Decomposition Analysis for a Binary Choice Model 7

Employer Learning and the Returns to Schooling 5 
Does the Recent Success of Some OECD

149 R. Lalive

J. C. van Ours

J. Zweimüller

J. DiNardo

K. F. Hallock

J.-St. Pischke

151 M. Ward

152 J. J. Dolado

F. Felgueroso

J. F. Jimeno

153 A. S. Kalwij

M. Gregory

154 M. Gerfin

M. Lechner

155

J. Hansen

156

C. Dustmann

F. Fabbri

157 P. Apps

R. Rees

A. Björklund

T. Eriksson

M. Jäntti

O. Raaum

E. Österbacka

159 P.- J. Jost

M. Kräkel

160

M. Lofstrom

161
V. Gimpelson
D. Treisman
G. Monusova

162 C. Dustmann

M. E. Rochina-

Barrachina
The Impact of Active Labor Market Programs and

Benefit Entitlement Rules on the Duration of Unemployment

Unions and the Labor Market for Managers

7

$5 / 00$

Gender, Salary and Promotion in the Academic

5

$5 / 00$

Profession

The Role of the Minimum Wage in the Welfare

3

$5 / 00$

State: An Appraisal

Overtime Hours in Great Britain over the Period 3

$5 / 00$

1975-1999: A Panel Data Analysis

Microeconometric Evaluation of the Active Labour Market Policy in Switzerland

$5 / 00$

The Duration of Immigrants' Unemployment Spells: $\quad 1 / 3$

Evidence from Sweden

$5 / 00$

Language Proficiency and Labour Market Per- 1

$5 / 00$

formance of Immigrants in the UK

Household Production, Full Consumption and $\quad 7$

$5 / 00$

the Costs of Children

Brother Correlations in Earnings in Denmark, 5

Finland, Norway and Sweden Compared to the United States

Preemptive Behavior in Sequential Tournaments

5

$5 / 00$

A Comparison of the Human Capital and Signaling Models: The Case of the Self-Employed and the Increase in the Schooling Premium in the 1980's

$6 / 00$

Public Employment and Redistributive Politics: 4

$6 / 00$

Evidence from Russia's Regions

Selection Correction in Panel Data Models: An 6 $6 / 00$ 
B. Nolan

Immigration into Ireland

168 G. S. Epstein

A. L. Hillman

169 R. Winkelmann

T. K. Bauer

K. F. Zimmermann

C. Dustmann

F. Windmeijer

172

D. Card M. Ward

179 E. Wasmer P. Weil

180 T. K. Bauer I. N. Gang 
Discretionary Measures of Active Labor Market

A. Zaidi

189 W. Arulampalam

G. Brunello
Is Unemployment Really Scarring? Effects of Unemployment Experiences on Wages

Racial and Economic Factors in Attitudes to Immigration

Joint Decisions on Household Membership and Human Capital Accumulation of Youths: The role of expected earnings and local markets

Absolute Risk Aversion and the Returns to Education

5

$8 / 00$

The Determination of Wages and the Gender

5

$8 / 00$ Wage Gap: A Survey

Regional Unemployment and Industrial

Restructuring in Poland

Overeducation, Undereducation, and the Theory of Career Mobility

5

$9 / 00$

Equilibrium Wage Arrears: A Theoretical and 4 Empirical Analysis of Institutional Lock-In

$8 / 00$

$8 / 00$

$8 / 00$

Options to Quit 
X. Gong 
213 X. Gong

A. van Soest

E. Villagomez

214 X. Gong

A. van Soest

215 J. Ermisch

M. Francesconi

216 F. Büchel

217 J. Hansen

R. Wahlberg

218 C. Dustmann

A. van Soest

219 F. Kramarz

T. Philippon

220 W. A. Cornelius

E. A. Marcelli

221

C. Grund

C. Grund 